\title{
METODE NAÏVE BAYES UNTUK MEMPREDIKSI PENGGUNAAN LISTRIK RUMAH TANGGA
}

\author{
Diana Fallo $^{1}$ dan Maria Sogen ${ }^{1}$ \\ ${ }^{1}$ Pendidikan Informatika, STKIP Citra Bina Nusantara, Kupang 85111 \\ Email Korespondensi : diana@ cbn.ac.id.
}

\begin{abstract}
ABSTRAK
Penelitian ini menggunakan metode Naïve Bayes untuk memprediksi penggunaan listrik setiap rumah tangga di Kota Kupang. Metode ini menggunakan bahasa pemrograman PHP dan MySql database. Hasil penelitian menunjukkan bahwa pengujian terhadap 50 data di Wilayah Kota Kupang. Penggunaan listrik dengan jumlah daya 1300 VA dan 900 VA sebagai berikut : pada keluarga yang berpenghasilan kisaran 2 juta sampai 3 juta serta memiliki tanggungan keluarga 4-7 orang, dengan jumlah peralatan listrik cukup dan jumlah pemakaian bola lampu tinggi, maka keluarga-keluarga tersebut tidak perlu melakukan penambahan daya (cukup). Sedangkan, jumlah daya $450 \mathrm{VA}$ pada kepala keluarga dengan penghasilan lebih dari 3 juta, serta memiliki tanggungan keluarga 4-7 orang, dengan jumlah peralatan listrik banyak (tinggi), dan jumlah pemakaian bola lampu tinggi maka keluarga-keluarga tersebut perlu melakukan penambahan daya (tambah daya). Hasil pengujian menemukan bahwa sebanyak 22 rumah tangga perlu melakukan penambahan daya (tambah daya). Sedangkan, 28 rumah tangga tidak perlu melakukan penambahan daya (cukup).
\end{abstract}

Kata kunci : Listrik, Nä̈ve Bayes, PHP, MY SQL Database

\section{PENDAHULUAN}

Listrik merupakan energi vital bagi keberlangsungan aktivitas manusia baik sebagai individu, kelompok masyarakat maupun dunia industri. Dengan kata lain energi listrik dapat dimanfaatkan untuk melakukan aktivitas dengan manfaat yang sangat besar[1]. Saat ini energi listrik sudah digolongkan sebagai kebutuhan pokok suatu daerah yang digunakan oleh empat kelompok pemakai listrik. Kelompok pemakai tersebut adalah kelompok rumah tangga, industri, bisnis, dan umum. Golongan rumah tanggalah yang merupakan kelompok pemakai energi listrik paling besar dalam setiap tahunnya. Didalam kelompok rumah tangga, listrik digunakan sebagai penerangan dan alat untuk mempermudah pekerjaan seharihari[2].

Propinsi Nusa Tenggara Timur (NTT) sebagai salah satu propinsi di Indonesia Bagian Timur yang tentunya memerlukan listrik sebagai roda penggerak perekonomian. Di NTT sendiri belum ada perusahaan besar yang membutuhkan kapasitas listrik besar selain dari Pabrik Semen Kupang. Penggunaan listrik terbanyak hanya dari industri rumah tangga, perkantoran, pertokoan dan perhotelan. Dalam hal mengetahui penggunaan listrik maka diterapkan beberapa teknik klasifikasi dalam penelitian ini yaitu Naïve Bayes. Tujuannya adalah untuk mengetahui apakah perlu adanya penambahan daya atau tidak dari listrik rumah tangga.

\section{Data Mining}

Menurut Kambe (2012) data mining merupakan proses untuk menemukan pola yang menarik dan pengetahuan dari sejumlah besar data[3]. Sumber data dapat berupa basis data, data warehouse, web, gudang informasi lain dan data yang berasal dari sistem yang dinamis. Selain itu penambangan data juga merupakan proses untuk mendapatkan informasi yang berguna dari gudang basis data yang besar. Terdapat beberapa tahap dalam proses penambangan 
data antara lain dapat dilihat pada Gambar 1 dibawah ini.

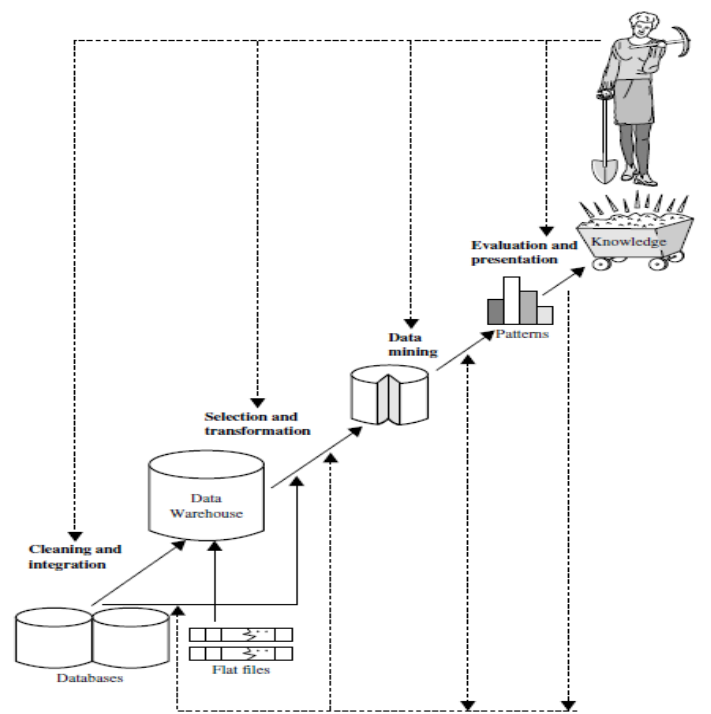

Gambar 1. Tahapan dalam Penambangan Data[3].

\section{Naïve Bayes}

Naïve pengklasifikasian dengan metode probabilitas dan statistik yang dikemukan oleh ilmuwan Inggris Thomas Bayes. Metode ini digunakan untuk memprediksi peluang di masa depan berdasarkan pengalaman di masa sebelumnya[4]. Definisi lain mengatakan Naïve Bayes merupakan teknik prediksi berbasis probabilitas sederhana yang berdasarkan pada penerapan teorema Bayes dengan asumsi independensi yang kuat.

$$
P(C \mid X)=\frac{P(X \mid C) P(C)}{P(X)}
$$

Dimana :

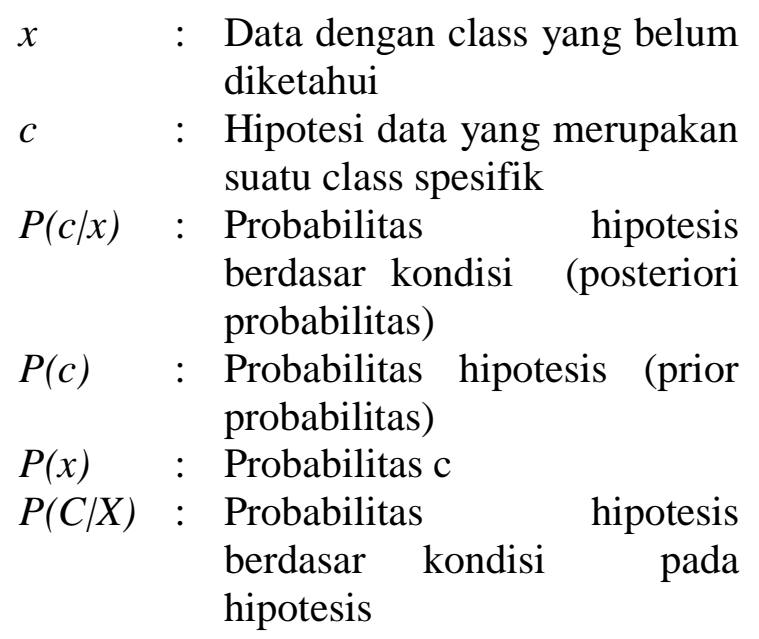

Persamaan (1) menjelaskan bahwa peluang masuknya sampel karakteristik tertentu dalam kelas C (Posterior) adalah peluang munculnya kelas $\mathrm{C}$ (sebelum masuknya sampel tersebut, seringkali disebut prior), dikali dengan peluang kemunculan karakteristik sampel pada kelas $\mathrm{C}$ (disebut juga likelihood), dibagi dengan peluang kemunculan karakteristik sampel secara global (disebut juga evidence). Karena itu, rumus diatas dapat pula ditulis sebagai berikut :

$$
\text { Pasterior }=\frac{\text { prior } \cdot x \cdot \text { likelihood }}{\text { Evidence }}
$$

Nilai Evidence selalu tetap untuk setiap kelas pada satu sampel. Nilai dari posterior tersebut nantinya akan dibandingkan dengan nilai-nilai posterior kelas lainnya untuk menentukan ke kelas apa suatu sampel akan diklasifikasikan. Penjabaran lebih lanjut rumus Bayes tersebut dilakukan dengan menjabarkan suatu kesamaan sebagai berikut :

$P\left(F_{i} \mid F_{j}\right)=\frac{P\left(F_{i} \cap F_{j}\right)}{P\left(F_{j}\right)}=\frac{P\left(F_{i}\right) P\left(F_{j}\right)}{P\left(F_{j}\right)}=P\left(F_{i}\right)$

Selanjutnya

$$
P(c \mid X)=P\left(x_{1} \mid c\right) P\left(x_{2} \mid c\right) \ldots P\left(x_{n} \mid c\right) P(c)
$$

Persamaan diatas merupakan model dari Teorema Naive Bayes yang selanjutnya akan digunakan dalam proses klasifikasi. Untuk klasifikasi dengan data kontinyu digunakan rumus Densitas Gauss :

$$
\left(X=x_{i} \mid Y=y_{j}\right)=\frac{1}{\sqrt{2 \pi \sigma_{i j}}} e^{-\frac{\left(x_{i}-\mu_{i j}\right)^{2}}{2 \sigma_{i j}^{2}}}
$$

Di mana :

$P \quad$ : Peluang

$X i$ : Atribut ke $i$

$x i \quad$ : Nilai atribut ke $i$

$Y \quad$ : Kelas yang dicari

$y i \quad$ : Sub kelas $Y$ yang dicari

$\mu \quad$ : mean, menyatakan rata - rata dari seluruh atribut

$\sigma \quad$ : Deviasi standar, menyatakan varian dari seluruh atribut. 
Adapun flowchart algoritma Naïve Bayes yaitu

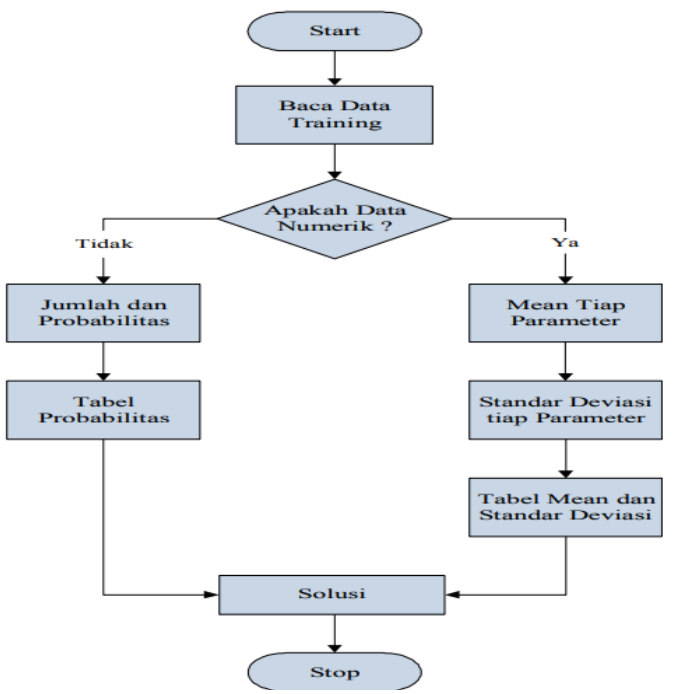

Gambar 2. Flowchart Algoritma Naïve Bayes (Bustami, 2014).

\section{METODE PENELITIAN}

Tahapan penelitian dilaksanakan dengan beberapa tahapan yaitu, pertama perijinan pengambilan data, kedua pengambilan data dengan cara menyebarkan kuesioner ke lokasi rumah tangga secara acak, ketiga data hasil kuesioner dilakukan analisa dan keempat data diimplementasikan ke dalam program. Tahapan penelitian dapat dilihat pada Gambar 3.

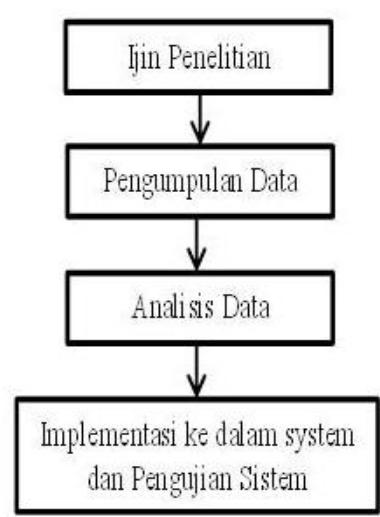

Gambar 3. Tahapan Penelitian.

\section{HASIL DAN PEMBAHASAN}

Adapun tahapan dari Metode Naïve Bayes antara lain :

\section{Data Training}

Daya listrik dibagi menjadi 3 bagian yaitu 450 VA, 900 VA, 1300 VA.
Penghasilan kepala keluarga terdiri dari $\leq$ Rp. 1.000.000, Rp. 2.000.000 - Rp. 3.000.000, $\geq$ Rp. 3.000.000. Untuk tanggungan keluarga dibedakan menjadi tanggungan untuk 1-3 orang, 4-7 orang dan $\geq 7$ orang. Sedangkan jumlah peralatan listrik dan jumlah bola lampu dikelompok menjadi 3 bagian yaitu tinggi, cukup dan kurang/rendah.

\section{Data Testing}

Data testing dari penelitian ini adalah sebanyak 50 data yang dapat dilihat pada Tabel 1.

Tabel 1. Tabel data testing penggunaan listrik rumah tangga.

\begin{tabular}{|c|c|c|c|c|c|}
\hline No & Daya & Penghasilan Kepala Keluarga & $\begin{array}{l}\text { Tanggungan } \\
\text { Keluarga }\end{array}$ & $\begin{array}{l}\text { Jumlah Alat } \\
\text { Listrik }\end{array}$ & $\begin{array}{l}\text { Jumlah } \\
\text { Bola } \\
\text { Lampu }\end{array}$ \\
\hline 1 & $1300 \mathrm{VA}$ & Rp. $2.000 .000-$ Rp. 3.000 .000 & 4-7 orang & Cukup & Tinggi \\
\hline 2 & $1300 \mathrm{VA}$ & $\geq \operatorname{Rp} .3 .000 .000$ & 4-7 orang & Cukup & Kurang \\
\hline 3 & $900 \mathrm{VA}$ & $\geq \operatorname{Rp} \cdot 3.000 .000$ & $1-3$ orang & Cukup & Rendah \\
\hline 4 & 450VA & Rp. $2.000 .000-$ Rp. 3.000 .000 & $1-3$ orang & Cukup & Rendah \\
\hline 5 & $900 \mathrm{VA}$ & Rp. $2.000 .000-$ Rp. 3.000 .000 & $1-3$ orang & Cukup & Tinggi \\
\hline 6 & $900 \mathrm{VA}$ & Rp. $1.000 .000-$ Rp. 1.500 .000 & 4-7 orang & Cukup & Rendah \\
\hline 7 & 450VA & Rp. $1.000 .000-R p .1 .500 .000$ & $1-3$ orang & Cukup & Rendah \\
\hline 8 & $1300 \mathrm{VA}$ & Rp. $2.000 .000-$ Rp. 3.000 .000 & $4-7$ orang & Cukup & Tinggi \\
\hline 9 & $900 \mathrm{VA}$ & Rp. $1.000 .000-R p .1 .500 .000$ & $1-3$ orang & Cukup & Rendah \\
\hline 10 & $900 \mathrm{VA}$ & $\geq \operatorname{Rp} .3 .000 .000$ & $\geq 7$ orang & Cukup & Tinggi \\
\hline 11 & $450 \mathrm{VA}$ & $\leq R p .1 .000 .000$ & $1-3$ orang & Kurang & Rendah \\
\hline 12 & $1300 \mathrm{VA}$ & 2 Rp. 3.000 .000 & 27 orang & Kurang & Rendah \\
\hline 13 & $900 \mathrm{VA}$ & Rp. $2.000 .000-$ Rp. 3.000 .000 & 4-7 orang & Cukup & Tinggi \\
\hline 14 & $900 \mathrm{VA}$ & Rp. $2.000 .000-$ Rp. 3.000 .000 & $1-3$ orang & Kurang & Rendah \\
\hline 15 & $900 \mathrm{VA}$ & Rp. $2.000 .000-$ Rp. 3.000 .000 & 4-7 orang & Cukup & Tinggi \\
\hline 16 & $1300 \mathrm{VA}$ & $\geq$ Rp. 3.000 .000 & $4-7$ orang & Cukup & Tinggi \\
\hline 17 & 900 VA & Rp. $2.000 .000-$ Rp. 3.000 .000 & 4-7 orang & Cukup & Tinggi \\
\hline 18 & $1300 \mathrm{VA}$ & Rp. $1.000 .000-$ Rp. 1.500 .000 & 4-7 orang & Kurang & Tinggi \\
\hline 49 & $900 \mathrm{VA}$ & $\leq \mathrm{Rp} \cdot 1.000 .000$ & 4-7 orang & Cukup & Rendah \\
\hline 50 & $1300 \mathrm{VA}$ & Rp. $2.000 .000-$ Rp. 3.000 .000 & 4-7 orang & Cukup & Tinggi \\
\hline dst & & & & & \\
\hline
\end{tabular}

\section{Hasil Pengujian Sistem}

Pengujian system ini menggunakan Aplikasi PHP My Sql terhadap 50 data. Hasil pengujian dapat gambar dibawah ini

\section{Halaman Login}

Halaman ini dapat di akeses secara online melalui situs http://kpu-sbd.tk/pekadaya/admin/beranda. Ini merupakan tampilan halaman dashboard dari system yang dibuat jika berhasil login maka akan 
masuk ke dalam aplikasi naïve bayes. Halaman login ditunjukkan pada Gambar 4.

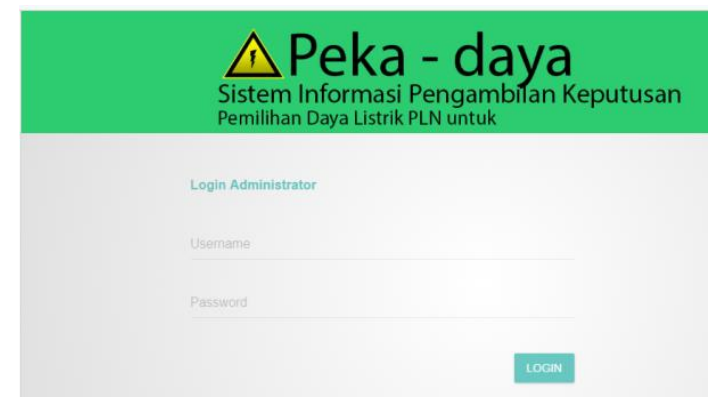

Gambar 4. Halaman Login

\section{Halaman Pelatihan}

Gambar 5 merupakan halaman data testing yang telah di implementasikan ke dalam aplikasi. Dari 50 data akan di uji. Data tersebut diambil secara acak pada rumah tangga di wilayah Kota Kupang. Selanjutnya data tersebut diuji apakah perlu penambahan daya atau tidak.

\section{Pelatihan}

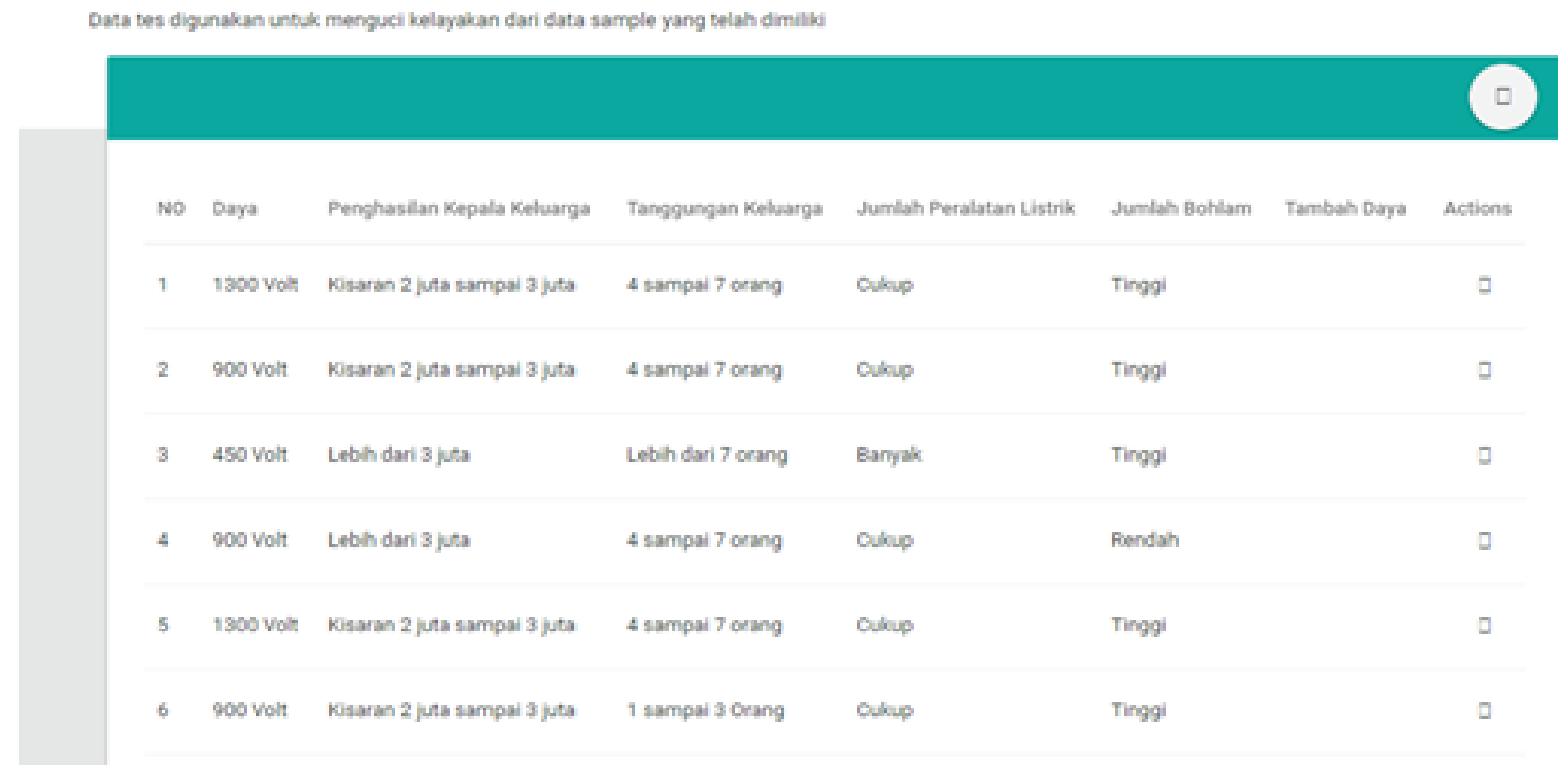

\section{Gambar 5. Data Testing}

\section{Halaman Pengujian Naïve Bayes}

Berdasarkan hasil pengujian yang terlihat pada Gambar 6. Ditemukan bahwa dari 50 data penggunaan listrik jumlah daya 1300 VA dan 900 VA dengan penghasilan kepala keluarga kisaran 2 juta sampai 3 juta, tanggungan keluarga 4-7 orang, jumlah peralatan listrik cukup dan jumlah pemakaian bola lampu tinggi tidak perlu melakukan penambahan daya (cukup). Sedangkan jumlah daya 450 VA dengan penghasilan kepala keluarga lebih dari 3 juta, tanggungan keluarga 4-7 orang, jumlah peralatan listrik banyak dan jumlah pemakaian bola lampu tinggi perlu melakukan penambahan daya (tambah daya) 


\section{Bayesian}

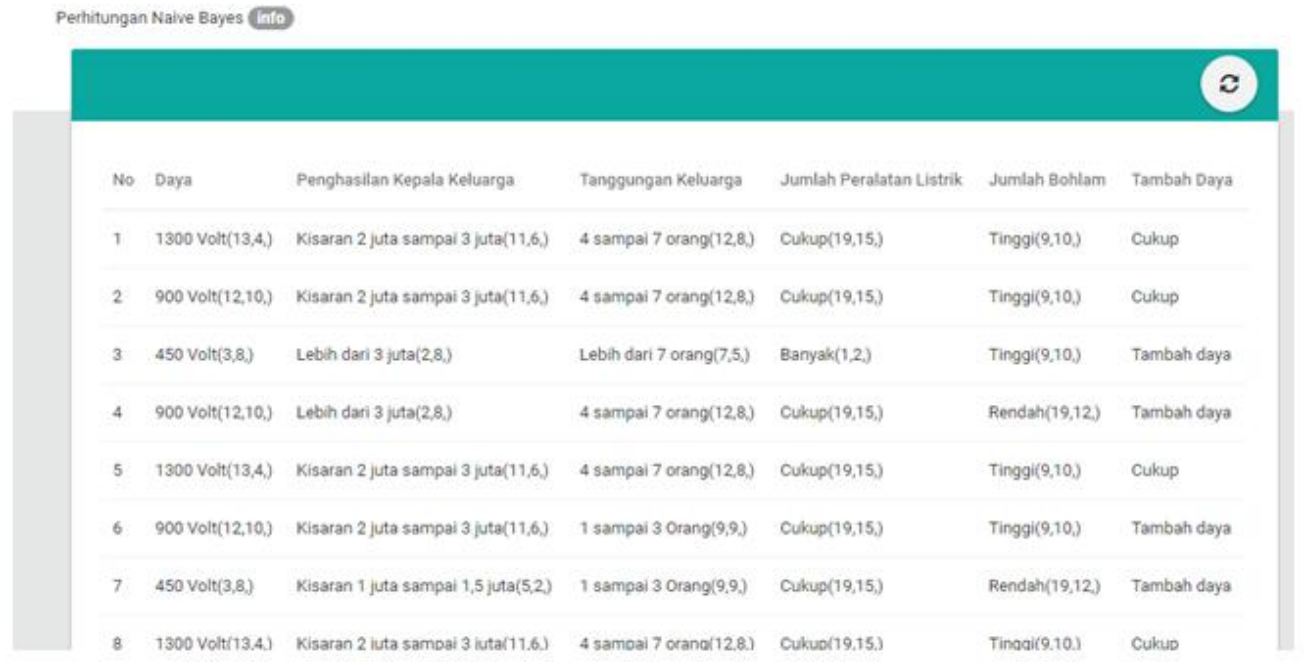

Gambar 6. Pengujian Naïve Bayes

Hasil pengujian terhadap 50 data ditemukan bahwa sebanyak 22 rumah tangga perlu melakukan penambahan daya (tambah daya). Sedangkan 28 rumah tangga tidak perlu melakukan penambahan daya (cukup).

\section{KESIMPULAN}

Hasil penelitian yang ditelah dilakukan tentang memprediksi penggunaan listrik rumah tangga di Kota Kupang dengan memanfaatkan Metode Naïve Bayes ditemukan bahwa terdapat 22 rumah tangga perlu melakukan penambahan daya dan 28 rumah tangga tidak perlu melakukan penambahan daya (cukup). Metode Naïve Bayes dapat bekerja dengan baik dalam memprediksi penggunaan listrik namun diharapkan penelitian selanjutnya dapat menggunakan beberapa metode yang lain untuk dapat membandingkan metode mana yang lebih akurat dalam mengklasifikasi data.

\section{UCAPAN TERIMAKASIH}

Ucapan terimakasih Penulis ingin ucapkan kepada pihak yang telah membantu antara lain :

1) DIKTI yang telah bersedia membiayai seluruh penelitian ini dalam bentuk dana penelitian bagi dosen pemula (PDP) tahun 2017.

2) STKIP CB menyelesaikan penelitian.
3) LP3M N Kupang yang telah memberikan dukungan dengan menyediakan fasilitas kampus untuk Penulis

4) STKIP CBN yang telah memberikan dukungan demi kelancaran penelitian ini.

\section{DAFTAR PUSTAKA}

[1] Y. P. Tanjung, S. Sentinuwo, and A. Jacobus, "Penentuan Daya Listrik Rumah Tangga Menggunakan Metode Decision Tree," 2016.

[2] C. S. Aji, "Faktor-Faktor Yang Mempengaruhi Konsumsi Listrik PLN Pada Kelompok Pelanggan Rumah Tangga (R-1 900 VA) di Kabupaten Purworejo tahun 2002-2008," Digilib UNS, 2010.

[3] J.Han, J.Pei, M.Kamber, Data Mining: Concepts and Techniques. 2012.

[4] Bustami, "Penerapan Algoritma Naive Bayes untuk Mengklasifikasi Data Nasabah Asuransi," J. Penelit. Tek. Inform. Univ. Ahmad Dahlan, 2014. 